\title{
Cytogenotoxicity of shakes added with synthetic micro ingredients
}

\begin{abstract}
The goal of this study was to evaluate the cytotoxicity and genotoxicity of diet shakes of three brands widely marketed in Brazil, named in this study of A, B and C. Assessments were carried out on root meristem cells of Allium cepa at exposure times 24 and 48 hours. The products (treatments) for A and B were evaluated at concentrations of $0.05 ; 0.10$ and $0.20 \mathrm{~g} / \mathrm{mL}$, and $\mathrm{C}$ at the concentration $0.08 ; 0.16$ and $0.32 \mathrm{~g} / \mathrm{mL}$. The diet products at the three concentrations tested, including those suggested as ideal for consumption by the manufacturers, at the two exposure times considered, were found to have significant antiproliferative effect on the meristems evaluated. However, none of the treatments caused significant cellular changes to the tissues of roots. Thus, the products tested were cytotoxic, but not genotoxic, to root meristem cells of $A$. cepa. Furthermore, it was observed that in all the treatments performed, in the three concentrations, the majority of the dividing cells were at prophase, not being observed cells at anaphase and telophase. Thus, it is suggested to conduct more in-depth studies on the cytotoxicity of these shakes in physiologically more complex bioassays for the verification and deepening of the data obtained here.
\end{abstract}

Volume I Issue 6 - 2017

Cleidiane Josefa dos Santos Veloso, Débora
Dayane Araújo Moura,Valtânia Ana de
Oliveira, Maria Eduarda de Sousa Silva,
Fabelina Karollyne Silva dos Santos, Ana
Paula Peron
Department of Biological Sciences, Federal University of Piaú

(UFPI), Brazil

Correspondence: Ana Paula Peron, Department of Biological Sciences, Federal University of Piauí (UFPI), Brazil,

Email anapaulaperon@ufpi.edu.br

Received: May 26, 2017 | Published: September 07, 2017

Keywords: weight loss, cell division, cellular changes, thickener, anti-wetting

\section{Introduction}

Brazil has experienced intense economic and social changes in its society in recent years, which has led to changes in its health and food model. These changes contributed to the reduction of poverty and social exclusion, but, on the other hand, led to an accelerated growth of overweight in individuals of different social classes Sousa et al. ${ }^{1}$ With the increase in the incidence of obesity, there was a growing insertion of products in the Brazilian market regarded as potent weight reducers, among which we can mention the powder shakes. Shakes are indicated to replace one or two daily meals, and are sold without restrictions in drugstores all over the country Cavichioli et $\mathrm{al}^{2}$ They are classified as diet foods because they have a balanced composition of vitamins, minerals, dietary fibers, and reduced amounts of carbohydrates and fatty acids, in order to supply the nutritional needs of the individual basically and in a balanced way Araújo et al. ${ }^{3}$ In Brazil, diet foods are generally standardized and authorized for consumption and commercialization by the National Health Surveillance Agency (ANVISA), through Ordinance 30 as of December 13, 1998, which approves the regulation on foods for weight control. ${ }^{4}$ However, diet shakes are also classified as industrialized foods because they are added with synthetic microingredients of flavor, coloring, anti-wetting, thickener, emulsifier and sweetener classes Sousa et al. ${ }^{5}$ The addition of these microingredients, among other characteristics, has the purpose of promoting total dilution of the powder, which results in the homogeneous appearance of the product when dissolved in water or milk, as well as reducing significantly the absorption capacity of air humidity or hygroscopic capacity of the shake during storage and once opened for consumption. They also soften the taste, smell and color of this food making it more attractive to the consumer. However, researchers such as Tonetto et al., ${ }^{4}$ Sardi et al., ${ }^{6}$ Carvalho et al. ${ }^{7}$ and ANVISA ${ }^{8}$ state that many food additives, such as flavoring, coloring, anti-wetting, thickener, emulsifiers and sweeteners, among others, raise doubts about their potential cytotoxic, genotoxic, mutagenic and carcinogenic effects. Thus, it is necessary to carry out studies that, through appropriate bioassays, evaluate the cellular toxicity of industrialized products, such as diet shakes, in order to properly provide the well-being of consumers. According to $\mathrm{Brasil}^{8}$ toxicological analysis on food additives and, especially, foods containing such compounds, are the basis for elaboration or modification of the documents that standardize the basic composition of foods and/or semi-industrialized and industrialized products, ${ }^{8}$ Sales et al. ${ }^{9}$ However, to date, there are no studies evaluating the toxicity of diet shakes in the scientific literature at national and international level. The root meristem of Allium cepa L. (onion) is considered in the scientific milieu as an efficient bioassay for the evaluation of the acute toxicity at the cellular level of chemical compounds due to the reduced chromosome number $(2 n=16)$, which favors detection of chromosomal or clastogenic alterations, mitotic spindle disturbances or aneugenic alterations, and disorders in the cell proliferation index. This test system is internationally accepted by research agencies as an assessment tool with accurate sensitivity for analysis of cytotoxicity, genotoxicity and mutagenicity of the substance of interest, since the results achieved demonstrate, in most cases, satisfactory similarity to those obtained though animal testing systems and in cell cultures Herrero et al. ${ }^{10}$ Neves et al., ${ }^{11}$ Lacerda et al., ${ }^{12}$ Tabrez et al. ${ }^{13}$ Gomes et al., ${ }^{14}$ Oliveira et al., ${ }^{15}$ Campos et al.,${ }^{16}$ Moura et al., ${ }^{17}$ Santana et al. ${ }^{18}$ Therefore, the goal of this study was to evaluate the cytotoxicity and genotoxicity of diet shakes in root meristem cells of $A$. серa, from three different highly commercialized brands in drugstores all over Brazil.

\section{Material and methods}

Diet shakes products from three different brands, referred to in this study as A, B and C, were purchased at a drugstore located in the municipality of Picos, State of Piauí, Brazil, in November 2016. The samples obtained were within the shelf life. Shakes evaluated in this work are marketed in powder form. To determine the concentrations to be analyzed as for toxicity at the cellular level, the form of preparation 
and ingestion indicated on the labels of each product was used as a parameter. Thus, brands A and B suggested diluting $30 \mathrm{~g}$ of the product in $300 \mathrm{~mL}$ water. Based on this information, we set the concentrations of $0.05 ; 0.10$ and $0.20 \mathrm{~g} / \mathrm{mL}$ for these shakes. Brand C, it was recommended to dilute $40 \mathrm{~g}$ of shake powder in $250 \mathrm{~mL}$ water, and then we set the concentrations of $0.08 ; 0.16$ and $0.32 \mathrm{~g} / \mathrm{mL}$. To prepare all concentrations, distilled water was used. For toxicity assessment, initially, onion bulbs were allowed to root in bottles with distilled water, at room temperature $\left( \pm 27^{\circ} \mathrm{C}\right)$, until the roots were $2.0 \mathrm{~cm}$ in length. For analysis of each diet shake sample, an experimental group with five onion bulbs was established. Before placing the roots in contact with their respective samples (treatments), some roots were collected and fixed to serve as control of the bulb itself. Then, the remaining roots were placed into their respective treatments for 24 hours, a procedure called 24-hour exposure time. After 24 hours, some roots were collected and fixed. After this procedure, the remaining roots of each bulb were returned to their respective treatments where they remained for additional 24 hours, which was called 48-hours exposure time. Next, roots were again taken and fixed. The 24 and 48 hours exposure times were chosen with the purpose of evaluating the action of milk diluted in more than one cell cycle. Roots were fixed in Farmer 3:1 (ethanol: acetic acid) for 24 hours. In each collection, on average, three roots were taken per bulb. The slides, on average 03 per bulb, were mounted according to Guerra et al., ${ }^{19}$ and analyzed under an optical microscope using 40x objective lens. For each onion bulb, we analyzed 1,000 cells, totalling 5,000 cells for each control, 24-hour exposure time and 48-hour exposure time of each treatment group under analysis. Thus, for each brand of diet shake, we analyzed a total of 15,000 cells. Cells were observed in interphase, prophase, metaphase, anaphase and telophase. From this analysis, the mitotic index (MI) was determined by means of the following equation: $\mathrm{MI}=$ (total number of cells in mitosis $\div$ total number of cells analyzed) $\mathrm{x} 100$. The MI value was a parameter used for the determination of the cytotoxic potential of the samples of diet shakes under study. We also evaluated the genotoxic potential of concentrations of diet shakes by the frequency of micronucleated cells, colchicine metaphases, anaphase and telophase bridges, cells with adhesion, nuclear buds and multipolar anaphases. The statistical analysis of data was performed by Chi-square test $(\chi 2)$, with probability level of $<0.05$, using the software BioEstat 3.0. ${ }^{20}$ Toxicity tests were carried out in duplicate to validate the results obtained.

\section{Results and discussion}

From the results in Table 1, it can be seen that all diet products, at the three concentrations and in the two exposure times considered, caused significant inhibition of cell division in the root meristems. Such a condition can be evidenced by comparing the mitotic indices obtained for the times 24 hours and/or 48hours of A, B, C to the cell division index observed for their respective controls. However, when the cell division indices were compared between the exposure times 24 and 48hours of the same treatment, they were not significantly different from each other for any of the diet shakes evaluated. The cytotoxic potential of industrialized products, such as the diet shakes evaluated here, can be determined by the increase or decrease in the mitotic index of cells of the tissues exposed to them. ${ }^{21,5}$ According to Caritá et al. ${ }^{22}$ cell division indices below the negative control, when considered significant, indicate the presence of agents whose toxic action impairs the growth and development of organisms subjected to these substances. In addition, Gomes et al., ${ }^{13}$ Sales et $a 1 .{ }^{23}$ and Moura et al. ${ }^{1}$ argue that the inhibition of cell proliferation triggered by cytotoxic compounds in tissues of intense cell proliferation and normal performance and/or no cell changes - such as the root meristems used herein to assess the toxicity of diet shakes-is extremely harmful to the organism, since it has the property of inhibiting or limiting the replacement of cells, altering the protein synthesis and, consequently, resulting in malfunction of the organ where it is located.

Still in (Table 1), it can be observed that in all the treatments performed, the majority of the cells in division are in prophase. No anaphase and telophase cells were observed in the meristems treated with the diet products. According to Marques et al., ${ }^{24}$ chemical agents present in the formulation of foods or industrialized products may inhibit the formation of the mitotic spindle in tissues of intense cellular proliferation. This can lead to two situations: the first would be the formation of polyploid cells at the end of cell division, giving rise to a tissue with aberrant cells. The other, and the most indicated to explain the result observed in the present study, is that the polyploid cells produced were eliminated from the root meristems exposed to the diet products evaluated, once the principle of the cell cycle is the formation of identical cells, and the presence of cells with great variation in the chromosome number would make cell functioning, and of the tissue itself, impracticable. Moreover, the evaluated diet products did not induce alterations in the mitotic spindle in the root tissues at a statistically significant frequency. As mentioned earlier, the formulation of diet shakes contains food additives of different classes. Although scarce, there are studies in the scientific literature that show that some of these micro ingredients have the potential to cause toxicity at the cellular level. Among the sweetening additives cited on the labels of the diet products evaluated in the present study are sucralose, sodium cyclamate and aspartame. In a study by Van EyK et al., ${ }^{25}$ through normal cell lines, Caco-2 (colon cells), HT-29 (colon cells) and HEK-293 (kidney cells), it can be verified that these food additives were cytogenotoxic to these bioassays at different times of analysis. Furthermore, Sasaky et al., ${ }^{26}$ using the comet bioassay, verified that sodium cyclamate was cytogenotoxic and clastogenic to the colon of rodents chronically treated via gavage with this microingredient. As for the anti-wetting agent used in the diet shakes formulation, the only one mentioned on the label of the products in question was silicon dioxide. Rajiv et al. ${ }^{27}$ reported that this additive drastically reduced cell division and induced a significant frequency of cellular alterations in human lymphocytes in culture of normal cells.

In relation to flavorings, the aroma and flavor ingredients mentioned on the labels of the diet products evaluated herein were those of chocolate and vanilla. Sales et al. ${ }^{9}$ and Silva et al. ${ }^{23}$ evaluated these flavorings in root meristem cells of $A$. cepa and verified that these additives, at all doses and times of analysis considered, drastically reduced the cell division of the tissues analyzed, being potentially cytotoxic. Gultekin et al. ${ }^{28}$ observed that these flavorings had the property of inducing significant damage to the mitotic spindle, and, consequently, the cellular division of premature erythrocytes of mice, expressively inducing the formation of micronucleated cells in the bone marrow of these animals. Also, according to ANVISA, food flavorings in general contain the chemical compounds diacetyl (2,3-butadione), whose main function is to fix the aroma and flavor in industrialized foods. Whittaker et al. ${ }^{29}$ evaluated the mutagenic potential of this chemical in a gene mutation assay using mouse lymphoma cells, line L5178Y, and found that diacetyl caused significant damage to the chromosome 11 loci of these cells. It also caused the functional loss of the locus of thymidine kinase enzyme in these animals. Further, More et al. ${ }^{30}$ reported that high concentrations of diacetyl are mutagenic and have the potential to replace thymine with guanine. This shift 
has the property of breaking the hydrogen and disulfide bonds of the tertiary structure of proteins, such as those involved in cell division. Thus, the results of cell-level toxicity investigations on the mentioned sweetening, anti-wetting and flavoring additives corroborate with the results obtained here with diet shakes. There were no studies in the scientific literature evaluating the toxicity, at the systemic and cellular level, of food additives of thickening, emulsifying and stabilizing action in general. The coloring mentioned on the label of the three diet products evaluated was caramel. Studies assessing the toxicity of this specific additive showed that it was not cytotoxic, genotoxic and mutagenic to the bioassays to which it was analyzed Sengar et al. ${ }^{31}$ Therefore, the observed results showed that the diet shakes analyzed had significant potential of causing toxicity to root meristem cells of A. сера. This result indicates that these foods should be evaluated in physiologically more complex bioassays, such as in animal testing systems, to validate and deepen the data obtained here, so as to guarantee the safety of consumers.

Table I TCII, total number of cells in interphase and undifferentiated cells; ET, exposure time; CO, control; MI, mitotic index; P, prophase; M, metaphase; A, anaphase; T, telophase; TCD, total number of dividing cells. TAC, total cellular alterations; $\mathrm{MI}$ values followed by different letters within the same treatment are significantly different by $\chi^{2}$ test, at $5 \%$.

\begin{tabular}{|c|c|c|c|c|c|c|c|c|c|}
\hline TR & Conc & ET & TCII & $\mathbf{P}$ & $\mathbf{M}$ & A & $\mathbf{T}$ & TCD & MI (\%) \\
\hline \multirow{9}{*}{ A } & & $\mathrm{CO}$ & 2293 & 702 & 712 & 694 & 599 & 2707 & $54.1^{\mathrm{a}}$ \\
\hline & \multirow[t]{3}{*}{$0.05 \mathrm{~g} / \mathrm{mL}$} & $24 \mathrm{~h}$ & 4063 & 923 & 14 & 0 & 0 & 937 & $18.7^{b}$ \\
\hline & & $48 \mathrm{~h}$ & 4091 & 901 & 8 & 0 & 0 & 909 & $18.2^{\mathrm{b}}$ \\
\hline & & $\mathrm{CO}$ & 2830 & 623 & 598 & 532 & 417 & 2170 & $43.4^{\mathrm{a}}$ \\
\hline & \multirow[t]{3}{*}{$0.10 \mathrm{~g} / \mathrm{mL}$} & $24 \mathrm{~h}$ & 4090 & 910 & 31 & 0 & 0 & 941 & $18.8^{\mathrm{b}}$ \\
\hline & & $48 \mathrm{~h}$ & 4100 & 900 & 25 & 0 & 0 & 925 & $18.5^{b}$ \\
\hline & & $\mathrm{CO}$ & 3350 & 794 & 723 & 604 & 599 & 2720 & $54.4^{\mathrm{a}}$ \\
\hline & \multirow[t]{2}{*}{$0.20 \mathrm{~g} / \mathrm{mL}$} & $24 \mathrm{~h}$ & 4162 & 799 & 39 & 0 & 0 & 838 & $16.8^{\mathrm{b}}$ \\
\hline & & $48 h$ & 4153 & 824 & 23 & 0 & 0 & 847 & $16.9^{b}$ \\
\hline \multicolumn{10}{|c|}{ diet shake B } \\
\hline \multirow[t]{5}{*}{ TR } & \multirow[t]{2}{*}{ Conc. } & ET & TCll & $P$ & M & A & $\mathrm{T}$ & $\mathrm{TCD}$ & MI (\%) \\
\hline & & $\mathrm{CO}$ & 2626 & 694 & 594 & 573 & 513 & 2374 & $45.5^{\mathrm{a}}$ \\
\hline & \multirow[t]{3}{*}{$0.05 \mathrm{~g} / \mathrm{mL}$} & $24 \mathrm{~h}$ & 4087 & 899 & 14 & 0 & 0 & 913 & $18.2^{b}$ \\
\hline & & $48 \mathrm{~h}$ & 4092 & 891 & 17 & 0 & 0 & 908 & $18.1^{b}$ \\
\hline & & $\mathrm{CO}$ & 2213 & 723 & 792 & 691 & 581 & 2787 & $55.7^{\mathrm{a}}$ \\
\hline \multirow[t]{5}{*}{ B } & \multirow[t]{3}{*}{$0.10 \mathrm{~g} / \mathrm{mL}$} & $24 \mathrm{~h}$ & 4078 & 913 & 9 & 0 & 0 & 922 & $18.4^{\mathrm{b}}$ \\
\hline & & $48 \mathrm{~h}$ & 4073 & 927 & 0 & 0 & 0 & 927 & $18.5^{b}$ \\
\hline & & $\mathrm{CO}$ & 2129 & 714 & 784 & 682 & 691 & $287 \mid$ & $57.4^{\mathrm{a}}$ \\
\hline & \multirow[t]{2}{*}{$0.20 \mathrm{~g} / \mathrm{mL}$} & $24 \mathrm{~h}$ & 4070 & 901 & 29 & 0 & 0 & 930 & $18.6^{\mathrm{b}}$ \\
\hline & & $48 \mathrm{~h}$ & 4069 & 918 & 13 & 0 & 0 & 931 & $18.6^{b}$ \\
\hline \multicolumn{10}{|c|}{ shake diet C } \\
\hline \multirow[t]{6}{*}{ TR } & \multirow[t]{2}{*}{ Conc. } & ET & TCII & $\mathrm{P}$ & $M$ & A & $\mathrm{T}$ & $\mathrm{TCD}$ & MI (\%) \\
\hline & & $\mathrm{CO}$ & 1180 & 984 & 982 & 941 & 913 & 3820 & $76.4^{\mathrm{a}}$ \\
\hline & \multirow[t]{3}{*}{$0.08 \mathrm{~g} / \mathrm{mL}$} & $24 \mathrm{~h}$ & 3098 & 1887 & 15 & 0 & 0 & 1902 & $38.0^{b}$ \\
\hline & & $48 \mathrm{~h}$ & 3108 & 1882 & 10 & 0 & 0 & 1892 & $37.8^{b}$ \\
\hline & & $\mathrm{CO}$ & 1293 & 941 & 999 & 944 & 823 & 3707 & $74 . I^{a}$ \\
\hline & \multirow[t]{3}{*}{$0.16 \mathrm{~g} / \mathrm{mL}$} & $24 \mathrm{~h}$ & $377 \mid$ & 1210 & 19 & 0 & 0 & 1229 & $24.6^{\mathrm{b}}$ \\
\hline \multirow[t]{4}{*}{ C } & & $48 \mathrm{~h}$ & 3661 & 1300 & 39 & 0 & 0 & 1339 & $26.8^{b}$ \\
\hline & & $\mathrm{CO}$ & 1573 & 974 & 923 & 811 & 719 & 3427 & $68.5^{\mathrm{a}}$ \\
\hline & \multirow[t]{2}{*}{$0.32 \mathrm{~g} / \mathrm{mL}$} & $24 \mathrm{~h}$ & 3899 & $110 \mid$ & 0 & 0 & 0 & 1101 & $22.0^{b}$ \\
\hline & & $48 \mathrm{~h}$ & 3976 & 1024 & 0 & 0 & 0 & 1024 & $20.5^{b}$ \\
\hline
\end{tabular}

\section{Conclusion}

The diet shakes evaluated were cytotoxic, but not genotoxic to root meristem cells of A. cepa. It is suggested that the three evaluated products interfered with the formation of the mitotic spindle of the cells of the tissues exposed to them, not allowing the cells to progress to anaphase. 


\section{Acknowledgements}

None.

\section{Conflict of interest}

The author declares no conflict of interest.

\section{References}

1. Moura Ag, Santana Gm, Ferreira Pmp, et al. Cytotoxicity of cheese and cheddar cheese food flavorings on allim cepa L. root meristems. Brazilian Jorunal of Biology. 2016;76(2):439-443.

2. Cavichioli B, Abourihan CLS, Passoni CMS. Monitoramento da administração de um suplemento como coadjuvante na perda de peso. Caderno da Escola de Saúde. 2012;1(7):90-110.

3. Araújo LMP, Fortes RC, Fazzio DMG. Análise do uso de dietas da moda por indivíduos com excesso de peso. J Health Sci Inst. 2013;31(4):388391.

4. Tonetto A, Huang A, Yoko J, et al. O uso de aditivos de cor e sabor em produtos alimentícios. São Paulo: Faculdade de Ciências Farmacêuticas; 2008 .

5. Sousa Lc, Silva Na, Boulhosa Rb. Avaliação da composição nutricional através da rotulagem de shakes utilizados como substitutos de refeições. Revista Eletrônica Estácio Saúde. 2016;5(2):78-90.

6. Sardi M, Haldemann H, Nordmann B, et al. Use of retailer fidelity card schemes in the assessment of food additive intake: sunset yellow a case study. Food Addit Contam Part A Chem Anal Control Expo Risk Assess. 2010;27(11):1507-1515.

7. Carvalho BDL, Sales IMS, Peron AP. Cytotoxic, genotoxic and mutagenic potential of UHT whole milk. Food Science and Technology. $2017 ; 3(2)$

8. Brasil. Agência Nacional de Vigilância Sanitária (BR). Portaria nº30, de 13 de janeiro de 1998, que aprova o Regulamento técnico referente a alimentos para controle de Peso, Brasília (DF): ANVISA: Springer; 1998.

9. Sales IMS, Santos FKS, Silva FCC, et al. Assessment toxicity of grape, plum and orange synthetic food flavourings evaluated in in vivo test Systems. Food Technology and Biotechnol. 2017;55(1):131-137.

10. Herrero O, Martín JP, Freire PF, et al. Toxicological evaluation of three contaminant of emerging concern by use of Allium cepa test. Mutat Res. 2012;743(1-2):20-24.

11. Neves ES, Ferreira PMP, Lima LHGM, et al. Action of aqueous extracts of Phyllanthus niruri L.(Euphorbiaceae) leaves on meristematic root cells of Allium cepa L. An Acad Bras Cienc. 2014;86(3):1131-1137.

12. Lacerda LP, Malaquias G, Peron AP. Antiproliferative action of aqueous extracts of Hymenaea stigonocarpa Mart. (Fabaceae) on the cell cycle of Allium cepa L. An Acad Bras Cienc. 2014;89:1147-1150.

13. Tabrez S, Sahkil S, Urooj M, et al. Genotoxicity testing and biomarker studies on surface water: an over view of the techniques and their efficacies. J Environ Sci Health C Environ Carcinog Ecotoxicol Rev. 2011;29(3):250-257.

14. Gomes KMS, Oliveira MVGAD, Carvalho FRDS, et al. Citotoxicity of food dyes sunset yellow (E-110), bordeaux red (E-123), and tatrazine yellow (E-102) on Allium cepa L. root meristematic cells. Food Science and Technology. 2013;3(1):218-223.

15. Oliveira MVA, Alves DDL, Lima LHGM, et al. Citotoxicidade dos corantes alimentares erythrosine (E-127), azul brilhante (E-133) e red 40 (E-129) em sistema-teste vegetal. Acta Scientiarum. Biological Science. 2013;35(4):557-562.
16. Carvalho FR, Moura AG, Rodrigues GF, Nunes NM, et al. Are salty liquid food flavorings in vitro antitumor substances? Anais da Academia Brasileira de Ciências. 2016;88(3):1419-1430.

17. More SS, Raza A, Vince R. The butter flavorant, diacetyl, forms a covalent adduct with 2-deoxyguanosine, uncoils DNA, and leads to cell death. J Agric Food Chem. 2012;60(12):3311-3317.

18. Santana GM, Deus MSM, Sousa JMC, Ferre et al. Antimitotic and antimutagenic action of the Hymenaea stigonocarpa bark on dividing cells. Braz J Biol. 2016;76(2):520-525.

19. Guerra M, Souza MJ. Como observar os cromossomos: um guia de técnicas em citogenética vegetal, animal e humana. Ribeirão Preto, SP, FUNPEC, Brazil: 2002. 200 p.

20. Ayres M, Ayres JRM, Ayres DL, et al. BioEstat 5.0 - Aplicações Estatísticas nas Áreas das Ciências Biológicas e Médicas. Belem, Brazíl: 2007.

21. Fernandes TCC, Mazzeo DEC, Marin-Morales MA. Mechanism of micronuclei formation in polyploidizated cells of A. cepa exposed to trifluralin herbicide. Pesticide Biochemistry ande Physiology. 2007;88:252-259.

22. Caritá R, Marin-Morales MA. Induction of chromosome aberrations in the Allium cepa test system caused by the exposure of seeds to industrial effluents contaminated with azo dyes. Chemosphere. 2008;72(5):722725 .

23. Silva SIO, Santana GM, Sales IMS, et al. Toxicidade em nível celular de aromatizantes alimentares associados entre si em diferentes doses. Acta Scientiarum. Biological Science. 2016;38:77-84.

24. Marques G, Dantas EBS, Lima LHGM, et al. Ação do suco do fruto de Morinda citrifolia L. em células de sistema-teste vegetal. Biotemas. 2013;27(1):143-146.

25. Van Eyk AD. The effect of five artificial sweeteners on Caco-2, HT-29 and HEK-293 cells. Drug Chem Toxicol. 2015;38(3):318-327.

26. Sasaki YF, Kawaguchi S, Kamaya A, et al. The comet assay with 8 mouse organs: results with 39 currently used food additives. Mutat Res. 2012;519(1-2):103-119.

27. Rajiv S, Jerobin J, Saranya U, et al. Comparative cytotoxicity and genotoxicity of cobalt (II, III) oxide, iron (III) oxide, silicon dioxide, and aluminum oxide nanoparticles on human lymphocytes in vitro. Hum Exp Toxicol. 2016;35(2):170-183.

28. Gultekin F, Doguc DK, Kulac E. Effects of maternally exposed coloring food additivies on receptor expressions related to learning and memory in rats. Food Chem Toxicol. 2013;56:145-148.

29. Whittaker P, Clarke JJ, San RH, et al. Evaluation of the butter flavoring chemical diacetyl and a fluorochemical paper additive for mutagenicity and toxicity using the mammalian cell gene mutation assay in L5178Y mouse lymphoma cells. Food Chem Toxicol. 2008;46(8):2928-2933.

30. More SS, Raza A, Vince R. The butter flavorant, diacetyl, forms a covalent adduct with 2-deoxyguanosine, uncoils DNA, and leads to cell death. J Agric Food Chem. 2012;60(12):3311-3317.

31. Sengar G, Sharma HK. Food caramels: a review. J Food Sci Technol. 2014;51(9):1686-1696.

32. Krishna KA, Goel S, Krishna G. SAR genotoxicity and tumorigenicity predictions for 2-MI and 4-MI using multiple SAR software. Toxicol Mech Methods. 2014;24(4):284-293. 